\title{
Growth, Performance and Carcass Yield of Broilers Fed Standard and Low Protein Feeds with Inclusion of Dietary Crude Testosterone
}

\author{
Adejinmi Olanike Olufunmilayo ${ }^{1}$, Williams Tolulope Julius ${ }^{2}$, Odetola Olubayo Michael ${ }^{1}$, Ngozi Okwelum ${ }^{3}$, \\ Abioja Monsuru Oladimeji ${ }^{2} \&$ Ojezele Gabriel ${ }^{1}$ \\ ${ }^{1}$ Federal College of Animal Health and Production Technology, Moor Plantation, Ibadan, Nigeria \\ ${ }^{2}$ Department of Animal Physiology, Federal University of Agriculture, Abeokuta, Nigeria \\ ${ }^{3}$ Institutes of Food Security, Environmental Resources and Agricultural Research, Federal University of \\ Agriculture, Abeokuta, Nigeria \\ Correspondence: Odetola Olubayo Michael, Federal College of Animal Health and Production Technology, \\ Moor Plantation, Ibadan, Nigeria. E-mail: odetolabayo@yahoo.com
}

Received: April 6, 2015 Accepted: May 26, 2015 Online Published: August 15, 2015

doi:10.5539/jas.v7n9p138 URL: http://dx.doi.org/10.5539/jas.v7n9p138

\begin{abstract}
Uses of exogenous growth a promoter are safe, improve performance and reduce production costs in poultry business. Our objectives were to evaluate the influence of dietary crude testosterone (CTE) inclusion on growth, performance and carcass yield of broilers fed standard- and low-protein diets. One hundred and eighty day-old Marshall strain of broiler chicks were randomly assigned to six treatments; T1, T2, T3, T4, T5 and T6. T1 served as control (for standard-protein diet (SPD)) without CTE. T2 were fed SPD with CTE inclusion for 8 weeks. T3 were fed SPD with inclusion of CTE during the finisher phase only (4 weeks). T4 was control for low- protein diet (LPD) without CTE inclusion for 8 weeks. T5 were fed LPD with CTE inclusion for 8 weeks and T6 were fed LPD with the inclusion of CTE at the finisher phase only. Birds had ad libitum access to feed, water, and routine medications were administered. Feed intake, water intake, feed conversion ratio, body weight gain including carcass yield were measured and analyzed according to procedures of SAS. The results of the experiment showed that there were significant differences $(\mathrm{P}<0.05)$ in all parameters measured except mortality, thigh, drumstick, proventriculus, neck and gizzard. However, birds on T2 performed best by attaining a live weight of $2098.00 \mathrm{~g}$ at 8 weeks and a FCR of 2.07. Profit per bird was significantly $(\mathrm{P}<0.05)$ influenced. Therefore, inclusion of CTE as growth promoter in commercial broiler production with low-protein diet can be adopted for profitable broiler production.
\end{abstract}

Keywords: carcass yield, poultry, natural growth promoter, profitability, varied protein diets

\section{Introduction}

Animal feeding is the major cost of production as it gulps $60 \%-80 \%$ of the entire production costs according to Larry (1993). It is therefore necessary to seek other alternative methods of enhancing performance of broilers with reduced costs. The use of growth promoters with less competition by other end user and producers which are readily available and at affordable prices brings a relief on this burden of high cost of production on poultry farmers. Growth promoters are chemicals and biological substances which are added to livestock feed with the aim of improving the growth of livestock in fattening; improving the utilization of feed and thereby enhancing profitability in production. Their mechanism of action varies; positive effects can be expressed through appetite, improved feed conversion, stimulation of the immune system and increased vitality, regulation of the intestinal micro-flora (Peric, Uscebrka, Zikic, Vranjes, \& Nollet, 2005). According to the National office of Animal Health (NOAH, 2001), growth promoters are used to help growing animals digest their feed more efficiently in order to get maximum benefit from it and allow them to develop rapidly.

There are different types of growth promoters and the two major ones known are antibiotics and hormones. Antibiotics are one of the most important growth stimulating compounds in livestock production but their use are often discouraged because of the residues in meat and eggs. Hormones which are major growth promoters have been used to stimulate growth in livestock production. They help to increase weight gain, feed efficiency and carcass quality of animals. The steroidal compounds used for anabolic purposes in food animals are estradiol, 
progesterone, and testosterone. Testosterone, or one of its physiologically active metabolites binds to receptors in muscle and stimulates increased incorporation of amino acids into protein, thus increasing muscle mass without a concomitant increase in adipose tissue (Reinhardt, 2013). Testosterone is effective in stimulating skeletal growth and protein metabolism through the synthesis of protein. In animals, testosterone or testosterone propionate, alone or in combination with other hormonally active substances, is used primarily to improve the rate of weight gain and feed efficiency (Annamaria, 2012). This study therefore was aimed at determining the growth, performance and carcass characteristics of broilers fed standard- and low- protein diets with inclusion of dietary crude testosterone (CTE).

\section{Method}

\subsection{Experimental Site and Design}

The experiment was carried out at Bora Poultry Experimental Site of the Federal College of Animal Health and Production Technology, Ibadan, Nigeria. A $2 \times 3$ factorial arrangement in a completely randomized design was adopted. One hundred and eighty (180) unsexed day-old broiler chicks of Marshall Strain were randomly assigned into 6 treatments (T1, T2, T3, T4, T5 and T6) with 3 replicates per treatment. Each replicate had 10 birds. Two types of diets were formulated (standard- and low- protein diets). The compositions of the starter and finisher of both the standard- and low- protein diets; are shown in Table 1.

Table 1. Composition of experimental diets (starter and finisher)

\begin{tabular}{|c|c|c|c|c|}
\hline \multirow{2}{*}{ Ingredients } & \multicolumn{2}{|c|}{ Standard (\%) } & \multicolumn{2}{|c|}{ Low protein (\%) } \\
\hline & Starter & Finisher & Starter & Finisher \\
\hline Maize & 50.50 & 53.80 & 50.00 & 53.00 \\
\hline Soybean meal & 21.00 & 16.00 & 15.00 & 10.00 \\
\hline Ground nut cake & 16.5 & 13.00 & 12.00 & 8.60 \\
\hline Palm oil & 2.20 & 5.95 & 4.00 & 7.60 \\
\hline Fish meal $(72 \%)$ & 2.00 & 2.20 & 2.00 & 2.00 \\
\hline Wheat offal & 2.00 & 3.00 & 11.00 & 12.90 \\
\hline Bone-meal & 2.00 & 2.05 & 2.00 & 2.00 \\
\hline Oyster-shell & 2.80 & 3.00 & 3.00 & 2.90 \\
\hline Premix* & 0.25 & 0.25 & 0.25 & 0.25 \\
\hline Methionine & 0.25 & 0.25 & 0.25 & 0.25 \\
\hline Lysine & 0.15 & 0.15 & 0.15 & 0.15 \\
\hline Salt & 0.35 & 0.35 & 0.35 & 0.35 \\
\hline Total & 100.00 & 100.00 & 100.00 & 100.00 \\
\hline \multicolumn{5}{|l|}{ Calculated analysis } \\
\hline Metabolisable energy (Kcal/kg) & 3000.97 & 3200.00 & 3000.70 & 3200.56 \\
\hline Crude protein $(\%)$ & 23.08 & 20.04 & 20.01 & 17.00 \\
\hline Ether extract $(\%)$ & 6.10 & 9.62 & 7.68 & 10.97 \\
\hline Crude fibre $(\%)$ & 3.39 & 3.08 & 3.53 & 3.31 \\
\hline Calcium (\%) & 1.38 & 1.20 & 1.41 & 1.71 \\
\hline Available phosphorus (\%) & 1.67 & 1.86 & 1.63 & 1.72 \\
\hline Lysine (\%) & 1.23 & 1.15 & 1.20 & 1.13 \\
\hline Methionine (\%) & 0.58 & 0.55 & 0.55 & 0.51 \\
\hline
\end{tabular}

Note. *Supplied per kg diet: Biotin $=40 \mathrm{mg} ; \mathrm{Zn}=58 \mathrm{mg} ; \mathrm{Fe}=5800 \mathrm{mg}$; Vit. $\mathrm{A}=1,000,000 \mathrm{IU}$; Folic acid $=500$ $\mathrm{mg}$; $\mathrm{Se}=120 \mathrm{mg}$; Nictotinic acid $=2800 \mathrm{mg} ; \mathrm{Cu}=700 \mathrm{mg} ; \mathrm{Mn}=4800 \mathrm{mg}$; Vit. $\mathrm{K}=1,500 \mathrm{mg}$; Riboflavin = $500 \mathrm{mg} ; \mathrm{Co}=300 \mathrm{~g}$.

\subsection{Description of Treatments}

The 180 day-old Marshal broilers were allotted into 6 dietary treatments (T1, T2, T3, T4, T5 and T6).

There were two varying levels of protein in the diets; the Standard-Protein diet (SPD) with $23 \%$ crude protein at starter phase and the low-protein diet (LPD) that has $20 \%$ crude protein at starter phase. 
T1 was fed SPD diet. CTE was not included in their water throughout the 8 weeks of production. T2 was also fed SPD diet. CTE was included in their water throughout 8 weeks. T3 was also given SPD diet. CTE was included in their water only at the finisher phase (4 weeks). T4 received LPD diet. CTE was not included in their water throughout 8 weeks. T5 also received LPD diet. CTE was included in their water throughout 8 weeks. T6 was also given LPD diet. CTE was included in their water only at the finisher phase (4 weeks). All the birds in all the treatments had ad-libitum access to feed and water.

\subsection{Preparation and Administration of CTE}

A total of 40 fresh cattle testes were procured from abattoir. The testes were crushed after removing the tunics (average weight of the testis $=159.18 \mathrm{gm}$ ), homogenized in a dilution of $30 \mathrm{~mL}$ of water per gramme of testis. A testicular fluid was obtained when it was centrifuged at $1500 \mathrm{rpm}$ for 5 minutes as a $30 \mathrm{~mL}$ crude testosterone. The CTE was then administered orally to birds in their drinking water as $30 \%$ solution (300 mL CTE to $700 \mathrm{~mL}$ of water). Daily water intake was measured.

\subsection{Experimental Procedure}

One hundred and eighty day-old Marshall broiler chicks were purchased from a commercial hatchery in Ibadan, south western Nigeria. The birds were reared together during the first seven days after which they were randomly assigned to 6 treatments as described above (T1-T6). Feed and fresh water were supplied on daily basis throughout the experimental period. All necessary medications and vaccinations were also administered. The daily left over in the feeding and watering troughs were weighed and deducted from feed and water offered to determine feed and water intake. At the end of each week, the birds were weighed to determine the weight gain. Average feed consumption on weekly basis was obtained from each treatment by dividing the total amount of feed consumed each week by the number of birds in each treatment. Body weight gain was measured weekly by taking the difference between the body weight for the given week from the body weight for the previous week. Feed conversion ratio was calculated by dividing the average feed intake by average weight gained. At the end of the experiment, 2 birds were randomly selected from each replicate and sacrificed. The carcasses were defeathered, weighed and cut into parts. These parts were then weighed and recorded.

\subsection{Economic Evaluation}

At the end of experiment, total cost of production for each treatment was calculated. Total cost of production comprises; costs of day-old broiler chicks, feed, medications and vaccinations, testes (for treatments on CTE), transportation and labour. This was divided by the number of birds in the treatment to obtain cost of production per bird. All the birds were weighed and sold at 650 naira per kg liveweight except for those sacrificed. Price of each bird was taken as total revenue. The difference between total revenue and total cost was regarded as profit.

\subsection{Statistical Analysis}

All data collected were subjected to analysis of variance using the general linear model (GLM) procedures of SAS (SAS Institute Incorporation, Cary, NC, USA; version 9.1). Means were separated using Duncan multiple range test in the same statistical package at $\mathrm{P}<0.05$ as a test of significance.

\section{Results}

The performance characteristics of the broilers fed different levels of protein and 30\% CTE at different stages of growth period are shown in Table 2. There were significant $(\mathrm{P}<0.05)$ differences in the performance characteristics (final liveweight, weight gain, feed intake and feed conversion ratio) of the broiler as influenced by the treatments. Birds on T2 had the highest live weight $(2098.00 \mathrm{~g})$ followed by the birds on T3 (2070.00 g). $\mathrm{T} 5, \mathrm{~T} 6, \mathrm{~T} 1$ and $\mathrm{T} 4$ followed in that order.

Table 2. Performance Characteristics of broilers fed varying levels of protein with inclusion of CTE

\begin{tabular}{llllllll}
\hline Parameters & $\mathbf{T}_{\mathbf{1}}$ & $\mathbf{T}_{\mathbf{2}}$ & $\mathbf{T}_{\mathbf{3}}$ & $\mathbf{T}_{\mathbf{4}}$ & $\mathbf{T}_{\mathbf{5}}$ & $\mathbf{T}_{\mathbf{6}}$ & \pm SEM \\
\hline Initial Weight (g) & 94.16 & 91.80 & 92.31 & 89.25 & 90.16 & 90.20 & 0.68 \\
Final Weight (g) & $1643.70^{\mathrm{d}}$ & $2098.00^{\mathrm{a}}$ & $2070.00^{\mathrm{b}}$ & $1633.70^{\mathrm{d}}$ & $2040.20^{\mathrm{c}}$ & $2026.95^{\mathrm{c}}$ & 0.90 \\
Weight Gain (g) & $1549.54^{\mathrm{d}}$ & $2006.20^{\mathrm{a}}$ & $1977.69^{\mathrm{b}}$ & $1544.45^{\mathrm{d}}$ & $1950.04^{\mathrm{bc}}$ & $1936.75^{\mathrm{c}}$ & 0.11 \\
Feed intake (g) & $4890.07^{\mathrm{c}}$ & $4123.67^{\mathrm{e}}$ & $4127.00^{\mathrm{e}}$ & $6021.10^{\mathrm{b}}$ & $4674.44^{\mathrm{d}}$ & $6664.74^{\mathrm{a}}$ & 0.88 \\
FCR & $3.18^{\mathrm{c}}$ & $2.07^{\mathrm{e}}$ & $2.09^{\mathrm{e}}$ & $3.89^{\mathrm{a}}$ & $2.40^{\mathrm{d}}$ & $3.44^{\mathrm{b}}$ & 0.02 \\
Mortality (\%) & 1.00 & 0.00 & 0.00 & 1.00 & 0.67 & 1.00 & 0.78 \\
\hline
\end{tabular}

Note. ${ }^{\mathrm{a}, \mathrm{b}, \mathrm{c}}$ : Means with different superscripts along the rows are significantly $(\mathrm{P}<0.05)$ different. 
The results on weight gain followed almost the same trend as the final live weight with birds on T2 having the highest value followed by birds on T3, T5, T6, T4 and T1 respectively. The results on feed intake showed that birds on T6 had significantly higher $(\mathrm{P}<0.05)$ feed intake than those in the other treatments followed by those on T4, T1, T5 T3 and lastly T2. Birds on T2 had the best FCR although the value was not significantly different from that of the birds on T3. This was followed by the birds on T5, T6, T1 and T4 respectively. There were no significant differences in the mortality of the birds across the treatments as well as water intake. Cost of feed per $\mathrm{kg}$ of birds was significantly $(\mathrm{P}<0.05)$ reduced by the treatments. Profit per bird was significantly $(\mathrm{P}<0.05)$ enhanced. Profit per bird was highest in T6 followed by T3, T5, T2, T4 and T1 respectively (Table 3).

Table 3. Cost analysis of broilers fed standard and low protein feed with the inclusion of dietary CTE

\begin{tabular}{llllllll}
\hline Parameter & T1 & T2 & T3 & T4 & T5 & T6 & \pm SEM \\
\hline Total cost ( $/$ /bird) & $820.80^{\mathrm{d}}$ & $1025.61^{\mathrm{a}}$ & $990.90^{\mathrm{b}}$ & $809.42^{\mathrm{d}}$ & $975.57^{\mathrm{b}}$ & $949.38^{\mathrm{c}}$ & 0.46 \\
Av. weight (kg/bird) & $1.64^{\mathrm{d}}$ & $2.10^{\mathrm{a}}$ & $2.07^{\mathrm{b}}$ & $1.63^{\mathrm{d}}$ & $2.04^{\mathrm{c}}$ & $2.03^{\mathrm{c}}$ & 0.90 \\
Price ( $\mathrm{N} /$ /kg liveweight) & 650.00 & 650.00 & 650.00 & 650.00 & 650.00 & 650.00 & \\
Total revenue ( $\$$ /bird) & $1,066.00$ & $1,365.00^{\mathrm{a}}$ & $1,345.50^{\mathrm{b}}$ & $1,059.50^{\mathrm{d}}$ & $1,326.00^{\mathrm{c}}$ & $1,319.50^{\mathrm{c}}$ & 0.78 \\
Profit ( $\$$ /bird) & $245.20^{\mathrm{d}}$ & $339.39^{\mathrm{c}}$ & $354.60^{\mathrm{b}}$ & $250.08^{\mathrm{d}}$ & $350.43^{\mathrm{b}}$ & $370.12^{\mathrm{a}}$ & 0.22 \\
\hline
\end{tabular}

Note. 1 US dollar (\$) is equivalent to 190 naira $(\mathrm{N})$.

The results on the carcass characteristics of the birds showed that there were significant $(\mathrm{P}<0.05)$ differences in the dressed weight, neck, thigh, drumstick, proventriculus and abdominal fat (Table 4).

Table 4. Carcass characteristics of broilers fed standard and low protein feed with the inclusion of dietary CTE

\begin{tabular}{llllllll}
\hline Parameters & T1 & T2 & T3 & T4 & T5 & T6 & \pm SEM \\
\hline Live weight (g) & $1828.0^{\mathrm{ab}}$ & $2033.0^{\mathrm{a}}$ & $2000.0^{\mathrm{ab}}$ & $1737.0^{\mathrm{b}}$ & $2042.0^{\mathrm{a}}$ & $1975.0^{\mathrm{ab}}$ & 30.40 \\
Weight after bleeding (\%) & 94.8 & 95.1 & 95.2 & 94.7 & 95.1 & 95.4 & 0.10 \\
Weight after plucking (\%) & 89.6 & 90.1 & 90.4 & 89.4 & 90.3 & 90.3 & 0.17 \\
Dressed weight (\%) & $80.0^{\mathrm{ab}}$ & $79.5^{\mathrm{ab}}$ & $79.6^{\mathrm{ab}}$ & $84.9^{\mathrm{a}}$ & $78.4^{\mathrm{b}}$ & $78.0^{\mathrm{b}}$ & 0.66 \\
Head (\%) & 2.70 & 2.60 & 2.60 & 2.80 & 2.50 & 2.50 & 0.04 \\
Neck (\%) & $4.80^{\mathrm{ab}}$ & $4.2^{\mathrm{b}}$ & $4.1^{\mathrm{b}}$ & $5.4^{\mathrm{a}}$ & $4.6^{\mathrm{ab}}$ & $4.4^{\mathrm{ab}}$ & 0.13 \\
Thigh (\%) & $13.1^{\mathrm{ab}}$ & $11.4^{\mathrm{b}}$ & $11.4^{\mathrm{b}}$ & $14.0^{\mathrm{a}}$ & $12.0^{\mathrm{ab}}$ & $12.3^{\mathrm{ab}}$ & 0.24 \\
Drumstick (\%) & $11.9^{\mathrm{a}}$ & $10.8^{\mathrm{ab}}$ & $10.1^{\mathrm{b}}$ & $12.1^{\mathrm{a}}$ & $10.9^{\mathrm{ab}}$ & $10.7^{\mathrm{ab}}$ & 0.18 \\
Wings (\%) & 8.8 & 7.2 & 7.5 & 8.6 & 7.8 & 8.1 & 0.18 \\
Gizzard (\%) & 2.2 & 2.1 & 2.3 & 2.6 & 2.3 & 2.3 & 0.08 \\
Gall bladder (\%) & 0.2 & 0.2 & 0.2 & 0.3 & 0.2 & 0.2 & 0.01 \\
Spleen (\%) & 0.2 & 0.2 & 0.2 & 0.2 & 0.2 & 0.2 & 0.03 \\
Liver (\%) & 2.2 & 2.2 & 2.0 & 1.8 & 1.9 & 2.1 & 0.07 \\
Heart (\%) & 0.5 & 0.5 & 0.5 & 0.5 & 0.5 & 0.5 & 0.01 \\
Lungs (\%) & 0.5 & 0.5 & 0.5 & 0.5 & 0.5 & 0.5 & 0.01 \\
Proventriculus (\%) & $0.53^{\mathrm{a}}$ & $0.49^{\mathrm{ab}}$ & $0.46^{\mathrm{ab}}$ & $0.51^{\mathrm{ab}}$ & $0.48^{\mathrm{ab}}$ & $0.44^{\mathrm{b}}$ & 0.01 \\
GIT (\%) & 6.0 & 5.1 & 5.3 & 5.8 & 4.9 & 5.0 & 0.23 \\
Crop (\%) & 0.7 & 0.7 & 0.7 & 0.7 & 0.7 & 0.7 & 0.01 \\
Breast meat (\%) & 21.5 & 21.0 & 19.6 & 23.1 & 20.7 & 20.4 & 0.44 \\
Back (\%) & 14.7 & 15.4 & 13.6 & 17.4 & 15.6 & 15.1 & 0.66 \\
Abdominal fat (\%) & $1.4^{\mathrm{b}}$ & $1.7^{\mathrm{ab}}$ & $1.4^{\mathrm{b}}$ & $2.1^{\mathrm{a}}$ & $1.8^{\mathrm{a}}$ & $1.9^{\mathrm{a}}$ & 0.08 \\
Shank (\%) & $5.0^{\mathrm{a}}$ & $4.4^{\mathrm{ab}}$ & $4.2^{\mathrm{b}}$ & $4.4^{\mathrm{ab}}$ & $3.8^{\mathrm{b}}$ & $4.1^{\mathrm{b}}$ & 0.09 \\
\hline
\end{tabular}

Note. GIT: Gastro intestinal tract.

The results on the dressed weight revealed that there were significant $(\mathrm{P}<0.05)$ differences among the treatments. T4 had the highest dressed weight of $79.9 \%$ followed by T1, T3, T2, T6 and T5 respectively. Relative 
weight of thigh and drumstick followed the same trend. Significant $(\mathrm{P}<0.05)$ differences were also recorded in the abdominal fat of the birds across the treatments. T4 had the highest abdominal fat percentage of 2.1, followed by T6, T5, T2, T1 and T3 respectively (Figure 8 ).

\section{Discussion}

The initial live weight of the birds showed no significant difference across the treatments. This means that significant difference in the measured parameters were not because of the influence of the initial body weight but rather the treatments. The weight gain showed that birds on $\mathrm{T} 2$ had the highest weight gain followed by those on T3. This shows that protein and CTE played significant role in influencing the weight gain of birds. This agrees with the reports of Cole (1977) and Williams (2001) that CTE enhanced growth protein anabolism and stimulated both muscle and bone developments. This result also showed that feeding SPD in broilers cannot be compromised no matter the level or the growth promoter that is included in the bird's diets. Birds on T6 had the highest amount of feed intake followed by those on T4 and T1. This shows that birds on lower protein level requires comparably higher feed intake to meet their body needs. This agreed with the reports of Damelto and Emmans (1975) and Calet (1976) that available amino acids depend on dietary protein and their deficiency increased feed intake while the surplus producing less fat carcass and promote feed conversion. The birds on SPD with CTE (T2) for eight weeks had the best FCR although it was not significantly different from the FCR of birds on SPD and CTE at the finisher period only. The birds on T4 fed LPD alone throughout the experimental period without CTE had the poorest FCR. This shows that the protein level of the diets and CTE played significant role in improving the efficiency of feed utilization of the birds.

The carcass yield as well as the relative weight of cut parts, especially the breast meat and thigh agreed with the reports of Berri (2000), Williams (2001), Nworgu (2006) and Egbunike, Williams, and Agiang, (2007) but in contrast with the findings of Pollock (1997). Relative weights of internal organs except for proventriculus were not affected by treatments. This agrees with the findings of Dizaji, Zakeri, Golbazfarsad, Faramarzy, and Ranjbari (2013) that growth promoters did not affect internal organs. The highest percentage of fat was recorded on broilers in T4 followed by T1. These were controls for both SDP and LPD. Contrary to the finding of the present study, Yamazaki, Murakami, Nakashima, Otsuka, Takada, and Abe (2007) reported that dietary protein level did not affect abdominal fat deposition in broiler chickens. However, the relative weight of abdominal fat increased significantly in low-protein-diet fed broilers in the report of Ardekani and Chamani (2012). One of the mechanisms involved in increasing level of fat in carcass in low-protein-diet fed chickens might be due to the resultant deamination and transamination of surplus amino acids to other metabolites and finally uric acid (Ardekani \& Chamani, 2012) The percentage of thigh in birds that did not use CTE (T1 and T4) were significantly higher than their counterparts on CTE. It is probable that CTE administered had a negative correlation with percentage of thigh in the birds.

It is important to note that profit per bird was significantly elevated by the inclusion of CTE inspite of feeding LPD feeds in T6. This showed the protein retention capacity of CTE. The birds on T6 were able to retain and utilized higher percentage of their protein through the effect of CTE ingested. This shows that CTE can be used as a growth promoter in broiler production to replace antibiotics which has engendered concerns over high incidence of antimicrobial resistance that results from their continuous use Dizaji, Zakeri, Golbazfarsad, Faramarzy, and Ranjbari (2013). Therefore for a broiler farmer producing about 1000 broilers in two months using LPD with the inclusion of 30\% CTE, the expected profit of his enterprise will be about 370,000 (three hundred and seventy thousand) naira or 1.85 million naira per annum ( 5 batches). The mortality records showed that there were no significant differences among the birds on the various dietary treatments.

\section{Conclusion}

It is concluded that $30 \%$ inclusion of CTE has no visible deleterious effect on broilers. SPD with inclusion of $30 \%$ CTE in broilers produced the best performance record; zero mortality, weight gain of $2006.20 \mathrm{~g}$ and final weight of $2098 \mathrm{~g}$, high carcass yield and reasonable profit. It is therefore recommended that poultry producers based on the economics of production costs can include $30 \%$ of CTE in broiler nutrition for enhance growth and profitability.

\section{References}

Annamaria, P. (2012). Steroid hormones in food producing animals: A bird's-eye view of veterinary medicine. In C. C. Perez-Marin (Ed.), In Tech. Retrieved from http://www.intechopen.com/books/a-bird-s-eye-view-of-v eterinary-medicine/title-steroid-hormones-in-foodproducing-animals-regulatory-situation-in-europe

Ardekani, H. M., \& Chamani, M. (2012). Fortify low protein diet with supplemented essential amino acids on 
performance, carcass characteristics and whole-body female broiler chickens. Annals of Biological Research, 3(5), 2208-2212.

Berri, C. (2000). Variability of sensory and processing qualities of poultry meat. World's Poultry Science Journal, 56(3), 209-224. http://dx.doi.org/10.1079/WPS20000016

Calet, C. (1976). Amino acid requirement for meat producing poultry. In B. Cole \& B. Lewis (Eds.), Poultry metabolism and nutrition (pp. 305-324). Neals and Swan Butter worth, Boston, London.

Cole, E. H. (1977). Veterinary Clinical Pathology (2nd ed.). W.B. Saunders Company Philadelphia, USA.

Damelto, J. P. F., \& Emmans, G. C. (1975). Amino acid requirement of the young turkey: Lysine and Arginine. British Poultry Science, 23, 433-446.

Dizaji, B. R., Zakeri, A., Golbazfarsad, A., Faramarzy, S., \& Ranjbari, O. (2013). Influences of different growth promoters on intestinal morphology of broiler chickens. European Journal of Experimental Biology, 3(2), $32-37$.

Egbunike, G. N., Williams, T. J., \& Agiang, E. A. (2007). Utilization of crude testis extract to enhance broiler production in the humid tropics. Global Journal of Agricultural Sciences, 7(1), 27-30. Retrieved from http://www.ajol.info/index.php/gjass/article/view/2354

Fetuga, B. L. (1984). Techniques in feed formulation. Paper presented at the feedmill management training workshop department of agriculture economics (Unpublished). University of Ibadan.

Komolafe, A. A, Ashaye, T. L., \& Agboola, A. A. (1980). Agricultural Science for West African Schools and Colleges (pp. 160-166). Evans Pub Nig.

Larry, E. N. (1993). Broiler feeding and management. Poultry International, 32(1), 70-72.

NOAH. (2001). National Office of Animal Health. Antibiotics for Animals. Retrieved October 28, 2001, from http://www.naoh.co.uk/issueol.htm

Nworgu, F. C. (2006). Prospects and Pitfalls of Agricultural Production in Nig. (1st ed., pp. 79-96). Blessed publishers, Ibadan, Nig.

Peric, L., Uscebrka G., Zikic D., Vranjes, M., \& Nollet, L. (2005). Effect of Biomass supplementation on the performance of broiler chicks: A Serbian study (pp. 304-306). Proceeding of the $15^{\text {th }}$ European Symposium on Poultry Nutrition, 25-29 September, Balatonfured, Hungary.

Pollock, D. L. (1997). Maximizing Yield. Poultry Science, 76, 1131-1133. http://dx.doi.org/10.1093/ps/76.8.1131

Reinhardt, D. C. (2013). Steroid Hormones. http://www.merckmanuals.com/vet/pharmacology/growth_promotan ts_and production.enhancers/steroid_hormones.html

SAS. (1999). Statistical Analytical System (Version 9.1). SAS Institute Incorporation, Cary, NC, USA.

Williams, T. J. (2001). Effect of crude testosterone on the growth of broiler chicks (M.Sc. Dissertation, p. 61). University of Ibadan, Nigeria.

Yamazaki, M., Murakami, H., Nakashima, K., Otsuka, M., Takada, R., \& Abe, H. (2007). Effect of cellulase supplementation in low-crude protein diets on performance, nitrogen retention, fat deposition, hepatic lipogenic and lopolytic enzyme activity in broilers. British Poultry Science, 48(2), 210-216. http://dx.doi.org/10.1080/00071660701252988

\section{Copyrights}

Copyright for this article is retained by the author(s), with first publication rights granted to the journal.

This is an open-access article distributed under the terms and conditions of the Creative Commons Attribution license (http://creativecommons.org/licenses/by/3.0/). 